\title{
Price Discrimination and Smuggling of AIDS Drugs
}

\section{Citation}

Hornbeck, Richard A. 2005. Price discrimination and smuggling of AIDS drugs. Topics in Economic Analysis and Policy (5)1: Article 16.

\section{Published Version}

doi:10.2202/1538-0653.1404

\section{Permanent link}

http://nrs.harvard.edu/urn-3:HUL.InstRepos:11186012

\section{Terms of Use}

This article was downloaded from Harvard University's DASH repository, and is made available under the terms and conditions applicable to Other Posted Material, as set forth at http:// nrs.harvard.edu/urn-3:HUL.InstRepos:dash.current.terms-of-use\#LAA

\section{Share Your Story}

The Harvard community has made this article openly available.

Please share how this access benefits you. Submit a story.

Accessibility 


\title{
Topics in Economic Analysis \& Policy
}

Volume 5, Issue 1

2005

Article 16

\section{Price Discrimination and Smuggling of AIDS Drugs}

\author{
Richard A. Hornbeck*
}

*MIT, hornbeck@mit.edu

Copyright (c) 2005 by the authors. All rights reserved. No part of this publication may be reproduced, stored in a retrieval system, or transmitted, in any form or by any means, electronic, mechanical, photocopying, recording, or otherwise, without the prior written permission of the publisher, bepress, which has been given certain exclusive rights by the author. Topics in Economic Analysis \& Policy is produced by The Berkeley Electronic Press (bepress). http://www.bepress.com/bejeap 


\title{
Price Discrimination and Smuggling of AIDS Drugs*
}

\author{
Richard A. Hornbeck
}

\begin{abstract}
Patent-holding pharmaceutical companies are shown to be imperfectly able to charge differential prices for AIDS drugs due to the potential for black market exchange. Thus, greater segmentation in the international market through additional barriers to smuggling would induce firms to charge lower prices for AIDS drugs in poorer countries. Without these additional barriers, widespread drug distribution through mandated lower prices or weakened patent protection in the developing world would result in smuggling, undercutting demand in developed markets and reducing firms' research incentives. By contrast, further market segmentation would allow policy makers to go beyond the induced price cuts and remove patent protection in many markets where the benefits to increased distribution would likely outweigh the losses to research incentives.
\end{abstract}

KEYWORDS: price discrimination, differential pricing, AIDS, arbitrage, smuggling

*I thank David Autor, Gary Becker, Steve Cicala, Valentin Estevez, David Genesove, Daniel Gottlieb, Thomas Hubbard, Victor Lima, and anonymous referees for helpful comments. Richard A. Hornbeck, Massachusetts Institute of Technology, Department of Economics, E52-391, 77 Massachusetts Avenue, Cambridge, MA, 02139. hornbeck@mit.edu. 
Hornbeck: Price Discrimination and Smuggling of AIDS Drugs

\section{Introduction}

Within the debate over proper responses to the AIDS epidemic, one contentious issue is how to encourage both the discovery and the distribution of medicines able to treat the disease. Without government intervention, there would be few incentives to research new medicines. As a consequence, governments encourage research by granting patents to pharmaceutical companies, allowing invented medicines to be priced far above their marginal cost of production. There has been considerable investment in developing AIDS drugs to the benefit of many, yet firms' chosen prices have made them unaffordable for millions worldwide.

If these firms were able to charge different prices to different groups of consumers, i.e., price discriminate, it could be possible to spread the use of AIDS drugs considerably while maintaining research incentives. The economics of price discrimination have been studied in depth (Phlips, 1983; Tirole, 1988) and it has been successful in distributing low-cost vaccines in the developing world (JFK, 1997). Price discrimination (a.k.a. Ramsey pricing, differential pricing, tiered pricing, equity pricing) is an intuitive mechanism for improving the distribution of AIDS drugs, as well (Hammer, 2002; Scherer and Watal, 2002). ${ }^{1}$ However, price discrimination is only possible to the extent that AIDS drugs sold at low prices could not be resold to those targeted for high prices.

Exporting cheap medicines from low-income countries to high-income countries is generally now contrary to domestic and international law, though the effectiveness of these laws is unclear. It is relatively easy to protect higher-priced markets from "generic" AIDS drugs produced elsewhere: more easily observed production and distribution are prevented by international law, production methods often remain secret, and consumers in richer markets are hesitant to use unknown drugs. However, if patent-holding firms were to distribute the same AIDS drugs to countries at vastly different prices, there would be large incentives to acquire the drugs in low-price countries and sell them in high-price countries, reducing firms' profits. Thus, in order to charge high prices in wealthy countries, pharmaceutical companies may be forced to charge higher prices than they would otherwise choose in poor countries. Alternatively, there could be little potential for arbitrage and firms do not find it in their interest to distribute drugs widely. Ultimately, this is a question to be answered by examining the available evidence.

Scherer and Watal find some evidence that firms in the 1990's charged lower prices for AIDS drugs in poorer countries, as one might expect of a successfully price-discriminating firm, though this effect diminished over time. Still, this finding leaves unanswered the crucial question of whether firms are fully able to charge differential prices. If so, then efforts to lower prices further

1 For a collection of policy-oriented discussions on these issues, see also Granville (2002). 
must focus on reducing firms' market power through price controls or selectively removing patent protections, a.k.a. "compulsory licensing." Alternatively, if firms are constrained in their ability to charge lower prices in poorer counties, then prices could be lowered by increasing firms' ability to price discriminate.

Outterson (2005) argues that the potential for smuggling is not a binding constraint for firms. The main evidence for this argument is the current lack of international smuggling, despite already large price differences. Later theoretical analysis will demonstrate, however, that this is not the proper empirical test. When there is patent protection and price discrimination is constrained by the potential for arbitrage, smuggling would not occur in equilibrium. Instead, prices would be kept high enough in poorer countries such that those seeking to exploit the potential for arbitrage would be kept just on the brink of the opportunity.

Hammer surveys the interaction of economic, political, and legal aspects of price discrimination of AIDS drugs but many fundamental questions remain unanswered. These include the key issues of whether allowing further price discrimination would increase welfare, ${ }^{2}$ if firms' current price discriminatory behavior is constrained, and, if so, what factors are creating these constraints.

Scherer and Watal outline why banning this "parallel trade" to allow price discrimination should result in welfare gains. However, allowing further price discrimination will rarely benefit all consumers and could reduce welfare. ${ }^{3}$ Section II examines the international market for AIDS drugs to determine whether further price discrimination would be beneficial. In the case of AIDS drugs, preventing smuggling from a small poor market to a large rich market to allow further price discrimination would increase total welfare.

To explore whether firms are currently fully discriminating and charging country-specific optimal prices, it is necessary to focus directly on smuggling incentives. Section III develops a simple model of a monopolist's pricing decision in a rich and a poor market with variable segmentation. When smuggling is a relevant threat, the low price elasticity of drug demand in richer markets would induce a firm to choose higher prices in poorer markets to discourage smuggling and enable higher prices in the richer market. Thus, the model implies that the threat of smuggling would lead to higher prices for poorer countries, rather than leading to the onset of significant smuggling.

Section IV uses price data surveyed immediately after the United Nations' Accelerating Access Initiative to test the relevance of a smuggling threat at a time when political variation across countries in the price negotiation process is minimal. After this standardized negotiation was available to each country, remaining price differences were significantly affected by a proxy for smuggling

2 A policy change will be said to increase social welfare when those made better off would be willing to compensate those made worse off, without the same then being true in reverse.

3 See Ganslandt and Maskus (2004) for how this could occur within the European Union. 
potential, rather than by variables that proxy for domestic demand. Thus, firms' pricing decisions reveal a binding "black market constraint," as they would otherwise obtain higher profits by lowering prices in poorer countries. Anecdotal evidence on the viability of smuggling and the concerns of pharmaceutical companies supports the conclusion that prices are constrained by the potential for black market exchange.

Section V outlines the implications for AIDS drug policy. Because the potential for smuggling constrains firms' prices, smuggling would be the expected outcome of future government efforts to reduce prices by weakening patent protection and/or using generic drugs. This would erode patent protection in all markets, reducing research incentives. Prices would remain high in poorer countries, because negotiated or generically produced low-price medicines would be smuggled out of poorer countries until market prices to obtain and consume the drugs approached their earlier levels. In the case of AIDS drugs, this outcome would be particularly problematic because sporadic access to the drugs would promote biological resistance to the drugs and encourage virus mutations.

Instead, efforts directed toward improving market segmentation would induce firms to price discriminate further, allow the international community to weaken patent law selectively in chosen countries, and facilitate negotiated bulk purchases or donations. This would encourage future research through both increased firm profits and the demonstrated commitment to intellectual property rights. Several policy practices, including some price controls and subsidies, undermine market segmentation and should be discarded.

\section{AIDS drug demand and the welfare effects of price discrimination}

The international market for AIDS drugs includes several firms with legal monopolies over different complementary drugs. Given this observation and the high price to marginal cost ratio, it is reasonable to approximate these firms' actions by considering those of a simple monopolist. Potential or actual generic competition can be seen as weakening this patent power, increasing the price elasticity of the monopolist's market and decreasing its size.

Consumers within a country pay roughly the same price for AIDS drugs, while there are substantial price differences between countries. Many countries distribute drugs through public health programs, which would complicate a quantitative welfare analysis but does not affect a qualitative analysis. It is adequate to assume that the monopolist sets a price in each country according to the standard model of third-degree price discrimination. As the ability to smuggle between markets varies from very costly to costless, the outcome moves from a single international monopolist price to country-specific monopolist prices. 
In general, it is difficult to determine the welfare effects of allowing a monopolist to move from a perfectly fluid market to one where third-degree price discrimination is possible. This would cause prices and monopolist distortions to increase in markets where demand is less elastic to price and decrease in more elastic markets. Thus, the overall change in total welfare depends on how much demand reacts to price changes at different price levels in the different markets.

Previous theoretical work has shown, under increasingly general assumptions, that price discrimination will only increase welfare if output expands (Schmalensee, 1981; Varian, 1985; Schwartz, 1990). It is less clear, however, whether the increase in output would be sufficient to increase welfare. Varian provides the intuition that it would increase welfare if "one of the markets has small demand over the price range where the other market has large demand."

Layson (1994) identifies two conditions under which eliminating price discrimination would likely close markets: a large market share and larger profit margin for the higher priced market. Both of these conditions are present in the AIDS drug market in the examined time period, where the West made up twothirds of the market by volume, and the ratio of profit margins on AIDS drugs was at least $8{ }^{4}$ Layson's rule of thumb, that the profit margin ratio should be greater than $(1+$ rich market share $) /$ rich market share, is strongly met as $8>>2.5$. Combined with the previous analysis, this suggests that further price discrimination would likely increase welfare.

For a continuum of markets, Malueg and Schwartz (1994) show that price discrimination would increase welfare when there are large differences in demand, i.e., demand dispersion. This is clearly the case in the AIDS drug market: despite prices differing by an order of magnitude, only $4 \%$ of the developing world's need for anti-retrovirals was met in 2002 and $15 \%$ in 2005. ${ }^{5}$

Finally, Hausman and MacKie-Mason (1988) note that while third-degree price discrimination will often increase static welfare, it is more likely to increase dynamic welfare, given the positive effects on research and development. Even under perfect patent protection, $R \& D$ incentives will often remain below the social optimum. Thus, further price discrimination of AIDS drugs would increase welfare through both improved drug distribution and higher research incentives.

4 In 2002, the time period analyzed later, the West's market share was approximately two-thirds (UNAIDS 2002b; BBC News, "Aids epidemic 'still in early stages." July 2, 2002) and the profit margin ratio is approximated as 8 assuming a yearly United States price of $\$ 13,000$, an average Latin American and Caribbean price of \$2,000, and an approximated uniform cost of $\$ 500$. By 2005, assuming few changes in Western drug consumption, the West's market share had fallen to around one-third (UNAIDS 2005). Still, Layson's condition would hold for the 2005 consumption data, even ignoring that the profit margin ratio would be much higher.

5 These figures would drop to near $2 \%$ if one considers the ratio of those with HIV/AIDS that needs treatment to be the same in the West and the developing world (UNAIDS 2005; UNAIDS 2002b; BBC 2002). See also footnote 16 on page 18. 


\section{A theory of optimal price discrimination with potential smuggling}

Despite large international price differences, it remains unclear whether firms are able to price discriminate perfectly. High prices and low market penetration in the developing world could reflect either pricing constraints due to the threat of cross-border smuggling, or naturally high monopolist prices in the face of inelastic drug demand. A testable hypothesis can be derived by considering a simple model of monopolist behavior with variable costs of smuggling that are affected by firms' security expenditures.

There are two markets in the model: a (rich) country with more inelastic demand at high prices and a (poor) country with more elastic demand at low prices. These will simply be referred to as the "rich" or "poor" market, where rich and poor country variables are denoted by uppercase and lowercase variables, respectively. The Monopolist will first choose quantities $Q, q$, and barriers $B$ with production costs $\mathrm{C}(Q+q){ }^{6}$ The Black Market then chooses an amount $s$ to buy in the poor country, smuggle to the rich country at cost $\mathrm{C}(s, q, B)$, and sell in the rich country along with the Monopolist, but at a discount factor $D .^{7}$

The Monopolist maximizes over choice of $Q, q, B$ :

$$
Q^{*} P(Q, s)+q^{*} p(q, s)-C(Q+q)-C(B)
$$

The Black Market maximizes over choice of s:

$$
\begin{aligned}
& s *[P(Q, s) * D-p(q, s)]-C(s, q, B) \\
& \text { Subject to: } 0 \leq s \leq q
\end{aligned}
$$

At first glance, using a revealed preference argument, smuggling must reduce the Monopolist's profits because the countries' consumption after smuggling was in the Monopolist's original production choice set. Furthermore, smuggling will not occur in any equilibrium because the corresponding choice by the Monopolist would be dominated by choosing the post-smuggling quantities and capturing the previous returns to the Black Market without paying the smuggling costs. ${ }^{8}$

6 The results would be the same if the agents choose prices rather than quantities.

7 The discount factor can represent an aversion to buying drugs on the black market or reflect any subsidies through government provision and implicit subsidies through the insurance market.

8 If the rich market had multiple consumer types, it is possible that the Monopolist could use the Black Market to implement more profitable, potentially more efficient, price discrimination (see Anderson and Ginsburgh 1999 for a similar argument). While theoretically possible, AIDS drug firms' aversion to smuggling reveals this situation to be empirically irrelevant to the AIDS drugs case. Compared to the motivating cases for Anderson and Ginsburgh, the poorer markets here have more substantial potential demand and there is less reason to expect much exploitable variation in consumers' discount factors, as opposed to different arbitrage costs for consumers. 
Figure 1. Perfect (- - -) and imperfect (-) third-degree price discrimination

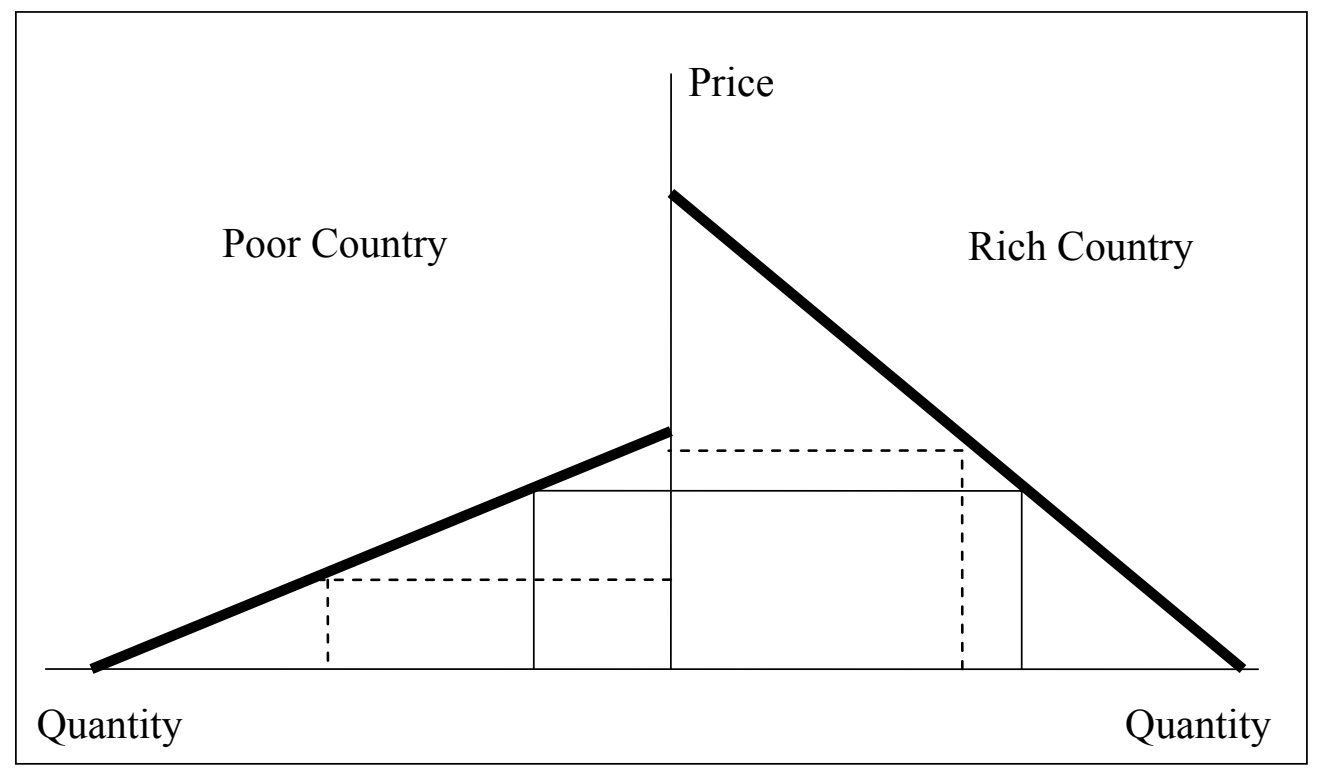

To demonstrate the workings of the model, assume a perfectly fluid market, where $D=1$ and $C(s, q, B)=0$. The Black Market would smuggle drugs to exploit any price difference, so the problem reduces to the single-market monopolist case where equilibrium prices are the same (thin solid lines in Figure $1)$. As $D$ decreases and $C(s, q, B)$ increases, the markets become more separate as the potential gains of smuggling fall and the costs rise. This allows the Monopolist to induce increasingly divergent prices until the standard perfect third-degree price discrimination case is reached (thin dashed lines in Figure 1).

More formally, using backward induction and beginning with the Black Market optimization, the first order condition for an interior solution is:

$$
[P(Q, s) * D-p(q, s)]+s *\left[P_{2}(Q, s) * D-p_{2}(q, s)\right]=C_{1}(s, q, B)
$$

where a subscript of one or two represents the partial derivative of the function with respect to the first or second term, respectively. Assuming perfect competition in the smuggling business, the second term on the left goes to zero, as smugglers do not consider their effect on overall smuggling opportunities. This term would also be close to zero if there were no smuggling and we considered the necessary condition for smugglers to enter the market. Thus, equation 3 simplifies to:

$$
P(Q, s) * D-p(q, s)=C_{1}(s, q, B)
$$


Equation 4 is an intuitive result: the discounted price difference is equal to the marginal cost of smuggling. By substituting this "black market constraint" into the firm's maximization problem, one can see how prices are bound together in the two countries. ${ }^{9}$

As smuggling becomes possible and profitable, prices in the two countries move from their separate respective profit-maximizing prices to new prices that maximize profits subject to this new black market constraint. Whether prices move more in the rich or poor country depends on the conditions outlined in Section II. Once prices are bound together in this tug-of-war between domestic demands for AIDS drugs, firms would mostly reduce the quantity sold to the poorer market to raise prices and protect the richer market.

If drugs were provided through the public sector in the poor country at a lower final price to consumers, the firm would not directly control the consumers' price. However, by setting the overall quantity distributed in that country, the firm determines the consumer with the lowest valuation to obtain drugs. That consumer's reservation price would be the price that exporters would have to pay to obtain supplies, which is the relevant price for the black market constraint.

The same implications hold in the case of many countries. Consider an ordering of countries, from the country with the lowest optimal single-market monopolist price to the country with the highest optimal price. Assuming no smuggling, there would be a trivial linear relationship between the single-market optimal price and the realized price (dashed line in Figure 2). If smuggling to all destinations were possible with a uniform constant marginal cost $c$ and the results from Section II held in the extreme such that the highest price $P$ remain fixed, then the price schedule would never decline below $P-c$ (solid line in Figure 2).

If the marginal cost to smuggling varied across countries, then prices to the left of the kink for country $i$ would be:

$$
p^{i}\left(q^{i}, s^{i}\right)=P(Q) * D-C_{1}^{i}\left(s^{i}, q^{i}, B^{i}\right)
$$

where $C_{1}^{i}\left(s^{i}, q^{i}, B^{i}\right)$ is the country-specific marginal cost of smuggling and $P(Q)$ is the price in the highest price country. Again, in a perfect information equilibrium with full patent protection, there would be no smuggling. Thus, the proper empirical test would not look for smuggling of AIDS drugs; rather, it would test for a lower bound in the price schedule for countries poor enough to be to the left of the kink in Figure 2.

9 For completeness, note that equation 4 need not hold if the Black Market desired to smuggle a quantity $\mathrm{s}>\mathrm{q}$ or $\mathrm{s}<0$ and was constrained to $\mathrm{q}$ and 0 , respectively. The first case would never be an equilibrium for the reasons described above. The second case would revert to the perfect third-degree price discrimination model with no Black Market. 
Figure 2. Monopolist price for a continuum of countries: no smuggling (- - -) and a uniform constant marginal cost $c$ of smuggling (-)

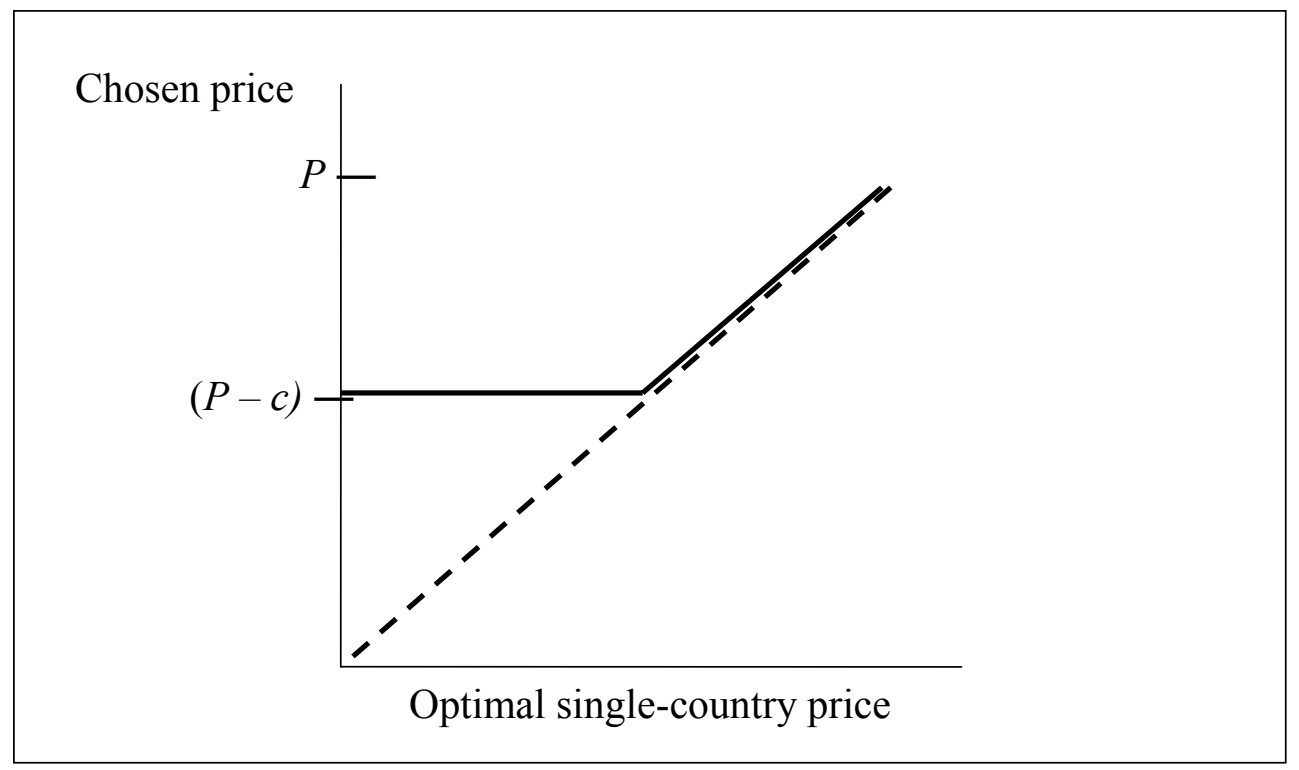

The main weakness of the model is its failure to account for negotiation elements of the price setting process. Depending on one's interpretation of international law, countries could threaten to eliminate patent protection and produce or import generic AIDS drugs. Particularly if there were uncertainty or imperfect information about when smuggling would occur, countries could possibly negotiate prices below the black market constraint. These effects would be especially important for pilot programs or otherwise for securing small quantities of drugs. The more basic smuggling incentive constraints, however, would be the dominant first-order effects in determining the pricing and flow of large quantities of drugs and, in particular, any amount close to what is needed in the developing world.

The model also gives some insight into firms' incentives to invest in barriers to smuggling, such as different packaging, tracking devices, or changes to the method of drug-administration. Substituting the black market constraint into the firm's maximization problem reveals a tradeoff between the firm's obtainable gross profits, which is an increasing function of barriers to smuggling, and the cost of barriers to smuggling. Maximizing net profit gives the condition:

$$
\pi^{\prime}(B)=C^{\prime}(B)
$$

The firm invests in barriers until its marginal cost equals the increase in gross profits. Because increased barriers also increase welfare in poorer countries to 
more than offset the declines in richer countries (see Section II), barriers to smuggling would be lower than is socially optimal without coordination between firms and country governments. Given that government and firm actions in producing barriers to smuggling are likely complements, i.e., one is less effective without the other, this coordination would be even more important.

This is a surprising conclusion given the antagonism between firms and governments and the existence of some government policies that undermine segmentation efforts. It is always difficult on equity grounds to suggest that poorer countries should contribute to international efforts, and an argument could be made that they should not be held responsible for anti-diversion efforts (Outterson, 2005). Poorer countries stand to benefit the most from increased price discrimination, however, and they should consider contributing resources and providing various forms of assistance, especially if richer countries are hesitant to go beyond their own narrow interests and subsidize anti-diversion efforts.

A pharmaceutical company does have an incentive to cultivate a stable market in developing countries, although it is a smaller incentive than is socially optimal. To the extent that the Monopolist might get public relations, advertising, or other benefits from providing drugs to poorer markets, private incentives to do so would be even larger. A company will not sacrifice its more profitable markets, but these potential gains do encourage action even though many believe private incentives to run completely counter to humanitarian goals.

\section{Testing the relevance of a smuggling threat}

One cannot assume immediately that the above black market constraint is binding, as the optimal monopolist price may be quite high relative to average incomes, particularly in countries with significant income dispersion. However, the analysis in Section III suggests a clear empirical test: if prices in poor countries decline with proxies for the optimal single-market price, it would suggest that prices have not reached the kink in Figure 2. In contrast, if prices are determined by proxies for differences in smuggling costs, it would indicate a binding black market constraint.

Empirical work on drug pricing, particularly for AIDS drugs, has faced several data problems. First, the proper measure of price is often unobserved, as the relevant price measure is that which the pharmaceutical company controls: at the point of sale from the pharmaceutical company to the public health system or insurance company, net of all rebates and hidden discounts. Second, because country-specific AIDS drug prices are the result of a complex negotiation process, political factors contributing to negotiation effectiveness and unobserved threats to produce or import generic drugs will substantially affect prices. 
Scherer and Watal (2002) examine Red Book wholesale list prices for AIDS drugs from 1995-1999, including 461 nation-product-year triplets, which is a large sample but of questionable quality as further discounts are common. They assume a constant discount of $20 \%$, but it would be likely to vary systematically across countries. To control for the effects of generic competition and the price negotiation process, the ideal variable would measure the effectiveness of threats to use generic drugs. Instead, Scherer and Watal include a dummy variable for whether the country granted any drug patents when the relevant drug was patented in the United States. They note, however, in their referenced working paper that the proxy is evidently not serving its desired purpose, as they find the unintuitive result that a country that grants patents pays significantly lower prices.

Scherer and Watal find that drug prices increase with per-capita GNP (PPP-adjusted) and decrease with the number of HIV/AIDS cases, although the magnitude of the effects is small. Scherer and Watal interpret the significantly positive coefficient on GNP as weak evidence for Ramsey pricing in poorer countries, while the effect of AIDS cases on price could have several theoretical implications. From the analysis in Section III, this would imply that the black market constraint is not binding. However, Scherer and Watal interact GNP with year dummies, finding stronger evidence for income-based price discrimination in 1995 and no effect by 1999, as prices fell by $8.7 \%$ annually. Based on the previous analysis here, this would imply an emerging black market constraint.

To address the price measurement and negotiation threat concerns, the empirical work here will use a survey by the Pan American Health Organization (PAHO) on prices for a year's treatment paid by public health ministries in 11 Latin American and Caribbean countries for two AIDS drug cocktails in May 2001 and May 2002 (Table 1). ${ }^{10}$ The survey was timed to capture prices before and after the United Nations' Accelerating Access Initiative, which made centrally organized price negotiations available to each country, potentially reducing the importance of unobserved political variables in the second time period. ${ }^{11}$ At this time, Latin America and the Caribbean represented $73 \%$ of antiretroviral treatment in the developing world (UNAIDS, 2002b). It is important to examine a substantial market so that the determined prices and quantities reflect meaningful profit opportunities and potential smuggling. By contrast, the theory in Section III would be less applicable to small pilot programs.

${ }^{10}$ The country sample often overlaps that used by Scherer and Watal, where 11 of their 18 nations were from Latin America and the Caribbean.

${ }^{11}$ See UNAIDS (2002a) for further discussion of the Accelerating Access Initiative. It is not possible to use differential progress in negotiations in the empirical analysis, as the only true exogenous aspect of the initiative was its availability to each country. It will be assumed that each country had an equally strong threat of using generic drugs, though some interpretations of international law would assign a great potential threat to those countries with domestic drug programs: Argentina, Columbia, and, in particular, Brazil. 
Hornbeck: Price Discrimination and Smuggling of AIDS Drugs

Table 1. AIDS drug prices in Latin America and the Caribbean

\begin{tabular}{|c|c|c|c|c|}
\hline & \multicolumn{2}{|c|}{$\begin{array}{l}\text { Price for a year's treatment } \\
\text { of } 3 \mathrm{TC} / \mathrm{AZT} / \mathrm{NVP} \text {, in } \$ \mathrm{US}\end{array}$} & \multicolumn{2}{|c|}{$\begin{array}{l}\text { Price for a year's treatment } \\
\text { of } 3 T C / A Z T / E F V \text {, in \$US }\end{array}$} \\
\hline & May 2001 & May 2002 & May 2001 & May 2002 \\
\hline Argentina & 1097.92 & & 5182.27 & 1339.49 \\
\hline Barbados & & 1339.49 & & 2406.93 \\
\hline Brazil & 1409.90 & 635.10 & 1416.20 & 1306.70 \\
\hline Colombia & & 5398.58 & & 3618.72 \\
\hline El Salvador & & & 6250.76 & $2650^{12}$ \\
\hline Haiti & & & 12568.70 & 1484.33 \\
\hline Honduras & & 1314.00 & & 1379.70 \\
\hline Jamaica & & & & 1226.40 \\
\hline Mexico & 5112.92 & 6509.17 & 3914.02 & 3819.52 \\
\hline Panama & & & & 2837.27 \\
\hline Trinidad \& Tobago & 1825.00 & 1281.69 & 1200.85 & 1332.35 \\
\hline Uruguay & 4671.39 & & 8013.83 & \\
\hline Venezuela & 8093.28 & & & \\
\hline
\end{tabular}

${ }^{12}$ Negotiations for El Salvador were completed shortly after the survey and so this data value was updated to approximately reflect the new 2002 price (reported in retrospect by Business Wire, "AIDS Healthcare Foundation Says Pharmaceutical Giants' Reduced AIDS Drug Pricing for Central America Simply Not Low Enough.” February 1, 2003). All other points were confirmed in press releases where possible, and no other contradictions were found. The results are similar using the previous El Salvador value of \$5,583, though the significance levels on the illicit drug variables drop to the $5 \%$ level due to the increased measurement error. 
Rather than relying on the absence of a link between income and prices, it would be preferable to find direct evidence of a binding black market constraint. Following equation 5, one could relate prices to the marginal cost of smuggling from each country. This is clearly difficult to measure, but useful proxies are the total value and per-capita value of all illicit drugs seized (UN ODCCP 2001). This is found by multiplying the quantity of each illicit drug seized in a country by the average wholesale price in Canada. ${ }^{13}$ A destination price was chosen to capture the potential value of smuggled goods and to avoid mechanical correlation between country illicit drug prices and the AIDS drug price.

The proxy is designed to capture the geographical, political, and economic factors that make smuggling AIDS drugs less costly. Those countries with more corrupt public systems, less effective law enforcement, or which are geographically more suited to smuggling should be likely candidates for smuggling of both illicit drugs and AIDS drugs. Also, companies might expect that initial AIDS drug smuggling would use the illicit drug trade infrastructure. In fact, a smuggling ring was recently discovered in the United States that had included the purchase, distribution, and sale of black market AIDS drugs with its illicit drug operations. ${ }^{14}$ After the Accelerating Access Initiative, it is less likely that these weaker political systems would affect AIDS drug prices simply through weaker negotiating.

There is a concern that the opposite relationship might hold: that a higher quantity of illicit drugs seized would be due to more effective law enforcement. This would be a particularly strong effect in a demand-driven market, such as for different American cities where the total quantity of illicit drugs demanded could be similar but drug seizures depended on the efficacy of local law enforcement. By contrast, for supply-driven markets in Latin America and the Caribbean, which largely export drugs to the United States and elsewhere, the quality of local law enforcement is a major influence on the illicit drug industry's choice of location for production and transportation. Thus, while better local law enforcement would mechanically cause higher drug seizures for a given level of illicit activity, one would expect the underlying amount of illicit activity to be much lower in a dynamic setting, resulting in lower overall seizures.

That better law enforcement is not the dominant determinant of illicit drug seizures passes a basic common-sense test: it is not generally believed that there is the same illicit drug activity in Argentina, Brazil, Columbia, and Mexico, and that the differences in drug seizures are explained by vastly more effective police operations in Columbia and Mexico. To the extent that higher quantities of seized drugs is partially mechanically due to better law enforcement, however, it would bias the empirical analysis against finding a positive effect on AIDS drug prices.

${ }^{13}$ The chosen price was for Canada because all prices were not available for the United States.

${ }^{14}$ Associated Press, “AIDS drugs 'smugglers' nabbed.” August 29, 2003. 
Simple scatterplots show the hypothesized positive relationship between AIDS drug prices in 2002 and the total value of illicit drugs seized, in millions, (Figure 3) or the per-capita value of illicit drugs seized (Figure 4). Data for both drug cocktails are shown, so some countries have two price observations. Both relationships have disadvantages. The first is driven by Columbia and Mexico. The second is prone to outliers such as Jamaica, which is a small country on the smuggling sea route to the United States, where per-capita values would overstate the quantity of drugs smuggled from the domestic population to abroad.

To test whether prices are unconstrained and reflect domestic demand, a wide range of other variables is considered. ${ }^{15}$ Gross national income per-capita is used, as the dominant effect one would expect is for a monopolist to choose higher prices in richer countries. A monopolist might aim to capture rents only from the wealthiest citizens, so the average income of the wealthiest $10 \%$ and the GINI coefficient of inequality are also used. Some countries may devote more resources to health spending, so health expenditure per-capita is included. Finally, those countries with more HIV/AIDS cases could potentially receive bulk discounts or otherwise face different price negotiations. The hope is that any other potentially important variables that are omitted do not vary much between these Latin American and Caribbean countries, particularly given the uniformly available negotiations under the Accelerating Access Initiative.

Tables 2 and 3 report the results of OLS and robust regressions of AIDS drug price on the various potential explanatory variables individually, with a dummy variable for drug cocktail type and a constant. While the sample size is quite small, the data are already aggregated over average prices of four drugs and these prices are the result of lengthy high-stakes negotiations, both of which should reduce noise in the price variable. OLS regressions and robust regressions designed to reduce the importance of outliers display a common result: involvement in the illicit drug trade is a statistically significant predictor of AIDS drug price, while proxies for domestic demand are not.

${ }^{15}$ Per-capita GNI, per-capita health expenditures, and population are for 2001 from the 2004 World Development Indicators in contemporary US\$. The number of HIV/AIDS cases, in thousands, is from the July 2002 UNAIDS report. Also from the 2004 WDI, the GINI coefficient and income shares were assumed to be constant over time as they were only available in select years: 2001 (Argentina, Brazil); 2000 (El Salvador, Jamaica, Mexico, Panama, Uruguay); 1999 (Columbia, Honduras); 1998 (Venezuela); 1992 (Trinidad and Tobago); none (Barbados, Haiti). These data were published after the negotiations, but were likely to have been known to the countries, firms, and United Nations negotiators. Preferred specifications are not in PPP terms, as pricing takes place on a global market exchange-rate basis, with the potential for cross-border flows, but little is changed when using PPP-adjusted values. AIDS rate was also used instead of AIDS cases, with little change to the results. 
Topics in Economic Analysis \& Policy, Vol. 5 [2005], Iss. 1, Art. 16

Figure 3. AIDS drug price in 2002 vs. total value of seized illicit drugs

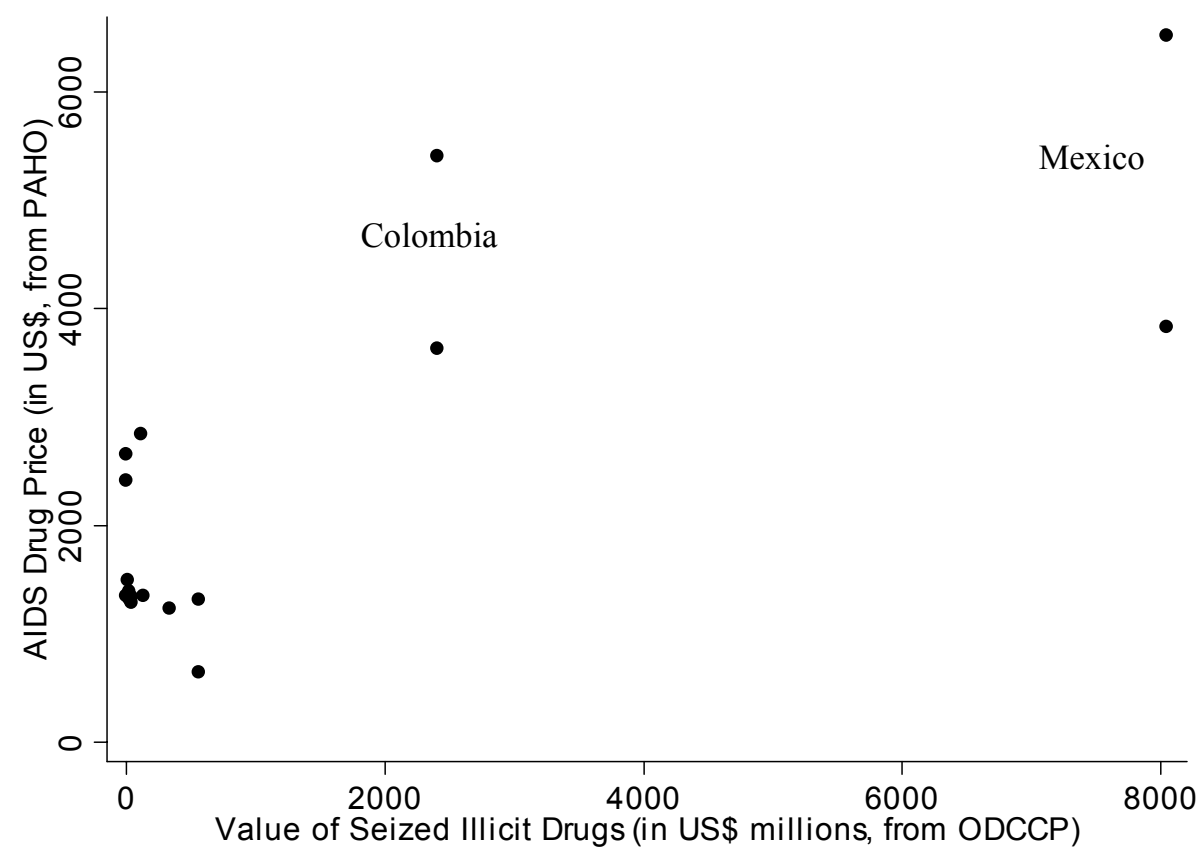

Figure 4. AIDS drug price in 2002 vs. per-capita value of seized illicit drugs

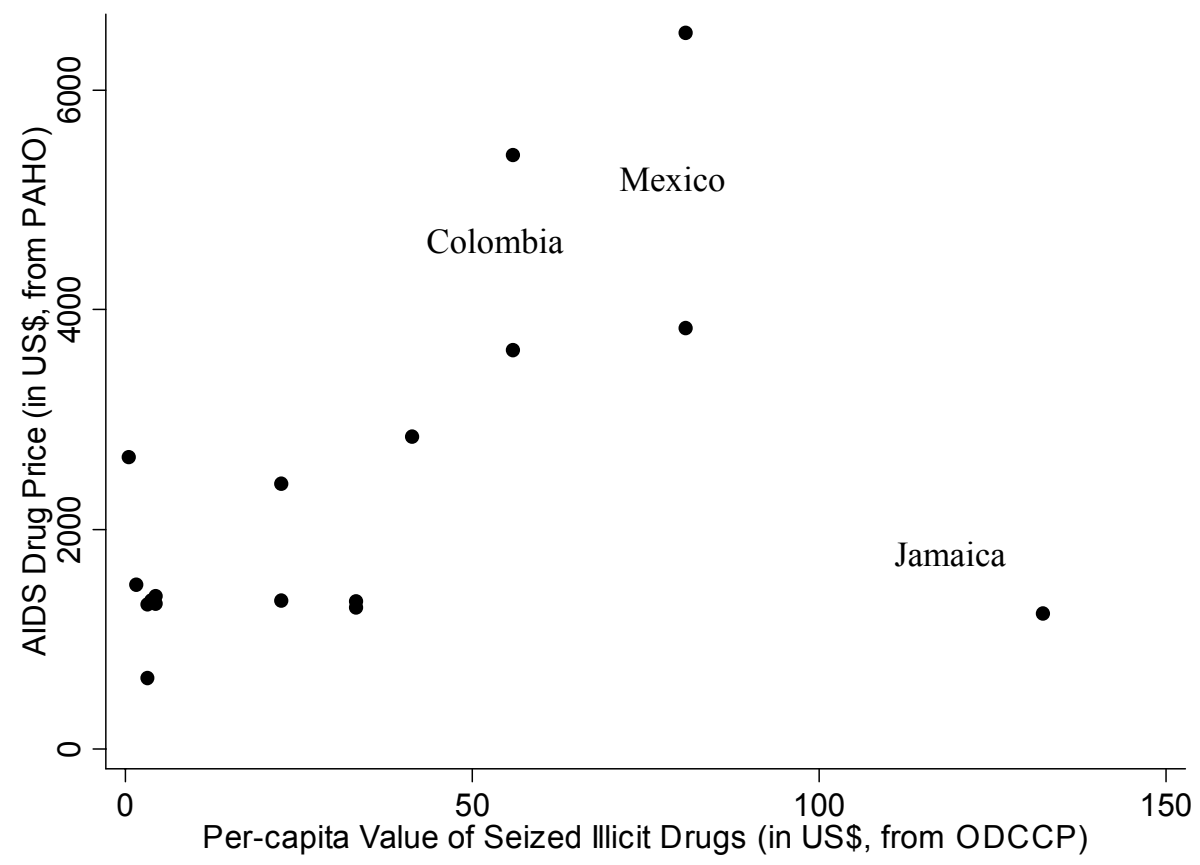


Hornbeck: Price Discrimination and Smuggling of AIDS Drugs

Table 2. OLS regression of 2002 AIDS drug price on:

\begin{tabular}{|c|c|c|c|c|c|c|c|}
\hline & (1) & (2) & (3) & (4) & (5) & (6) & (7) \\
\hline Drug Money & $\begin{array}{c}0.475 \\
(0.105)^{* *}\end{array}$ & & & & & & \\
\hline $\begin{array}{r}\text { Drug Money } \\
\text { per-capita }\end{array}$ & & $\begin{array}{c}20.8 \\
(10.2)+\end{array}$ & & & & & \\
\hline GNI per-capita & & & $\begin{array}{l}-0.010 \\
(0.158)\end{array}$ & & & & \\
\hline $\begin{array}{l}\text { GNI per-capita, } \\
\text { top } 10 \%\end{array}$ & & & & $\begin{array}{c}0.050 \\
(0.066)\end{array}$ & & & \\
\hline $\begin{array}{l}\text { GINI } \\
\text { coefficient }\end{array}$ & & & & & $\begin{array}{c}73.8 \\
(68.0)\end{array}$ & & \\
\hline $\begin{array}{l}\text { Health exp. } \\
\text { per-capita }\end{array}$ & & & & & & $\begin{array}{l}-0.146 \\
(2.14)\end{array}$ & \\
\hline $\begin{array}{l}\text { HIV/AIDS } \\
\text { cases }\end{array}$ & & & & & & & $\begin{array}{l}-1.41 \\
(2.24)\end{array}$ \\
\hline EFV dummy & $\begin{array}{l}-246 \\
(564)\end{array}$ & $\begin{array}{l}-643 \\
(766)\end{array}$ & $\begin{array}{l}-624 \\
(877)\end{array}$ & $\begin{array}{c}-893 \\
(1,020)\end{array}$ & $\begin{array}{l}-748 \\
(998)\end{array}$ & $\begin{array}{l}-620 \\
(873)\end{array}$ & $\begin{array}{l}-666 \\
(865)\end{array}$ \\
\hline Constant & $\begin{array}{c}1,867 \\
(489)^{* *}\end{array}$ & $\begin{array}{l}2,049 \\
(704)^{*}\end{array}$ & $\begin{array}{l}2,792 \\
(989)^{*}\end{array}$ & $\begin{array}{c}2,339 \\
(1,229)^{+}\end{array}$ & $\begin{array}{c}-911 \\
(3,715)\end{array}$ & $\begin{array}{c}2,787 \\
(916)^{* *}\end{array}$ & $\begin{array}{c}2,975 \\
(783)^{* *}\end{array}$ \\
\hline Adjusted R ${ }^{2}$ & 0.55 & 0.15 & -0.10 & -0.06 & -0.01 & -0.10 & -0.07 \\
\hline Observations & 17 & 17 & 17 & 14 & 14 & 17 & 17 \\
\hline
\end{tabular}

Table 3. Robust regression with Huber weights of 2002 AIDS drug price on:

\begin{tabular}{|c|c|c|c|c|c|c|c|}
\hline & (1) & (2) & (3) & (4) & (5) & (6) & (7) \\
\hline Drug Money & $\begin{array}{c}0.675 \\
(0.110)^{* *}\end{array}$ & & & & & & \\
\hline $\begin{array}{r}\text { Drug Money } \\
\text { per-capita }\end{array}$ & & $\begin{array}{c}30.7 \\
(5.3)^{* *}\end{array}$ & & & & & \\
\hline GNI per-capita & & & $\begin{array}{c}0.015 \\
(0.105)\end{array}$ & & & & \\
\hline $\begin{array}{l}\text { GNI per-capita, } \\
\text { top } 10 \%\end{array}$ & & & & $\begin{array}{c}0.042 \\
(0.076)\end{array}$ & & & \\
\hline $\begin{array}{l}\text { GINI } \\
\text { coefficient }\end{array}$ & & & & & $\begin{array}{l}74.0 \\
(74.5)\end{array}$ & & \\
\hline $\begin{array}{l}\text { Health exp. } \\
\text { per-capita }\end{array}$ & & & & & & $\begin{array}{l}0.040 \\
(1.44)\end{array}$ & \\
\hline $\begin{array}{l}\text { HIV/AIDS } \\
\text { cases }\end{array}$ & & & & & & & $\begin{array}{l}-1.18 \\
(1.38)\end{array}$ \\
\hline EFV dummy & $\begin{array}{c}569 \\
(454)\end{array}$ & $\begin{array}{c}802 \\
(298)^{*}\end{array}$ & $\begin{array}{c}809 \\
(587)\end{array}$ & $\begin{array}{c}-622 \\
(1,176)\end{array}$ & $\begin{array}{c}-473 \\
(1,094)\end{array}$ & $\begin{array}{c}806 \\
(587)\end{array}$ & $\begin{array}{c}835 \\
(533)\end{array}$ \\
\hline Constant & $\begin{array}{l}1,110 \\
(393)^{*}\end{array}$ & $\begin{array}{c}639 \\
(293)^{*}\end{array}$ & $\begin{array}{c}1,215 \\
(662)^{+}\end{array}$ & $\begin{array}{c}2,169 \\
(1,417)\end{array}$ & $\begin{array}{l}-1,196 \\
(4,070)\end{array}$ & $\begin{array}{c}1,265 \\
(615)^{+}\end{array}$ & $\begin{array}{l}1,391 \\
(482)^{*}\end{array}$ \\
\hline Adjusted $\mathrm{R}^{2}$ & 0.71 & 0.70 & -0.01 & -0.12 & -0.06 & -0.01 & 0.08 \\
\hline Observations & 16 & 16 & 17 & 14 & 14 & 17 & 17 \\
\hline
\end{tabular}


Combined with the theory from Section III, the results in columns 1 and 2 of Tables 2 and 3 imply that the potential for AIDS drug smuggling is the cause of high AIDS drug prices in poorer countries. Firms appear to be sacrificing profits in poorer countries by maintaining high prices in order to protect their other markets. This revealed binding black market constraint indicates that a further decline in prices without additional barriers to smuggling would result in smuggling. While countries in Latin America and the Caribbean pay lower prices on average than does the United States, poorer countries within the region do not obtain further lower prices. This is contrary to some public statements and expectations, though in accordance with the findings by Scherer and Watal in later time periods.

Tables 4 and 5 report OLS and robust regressions with combinations of demand proxies and illicit drug variables. The sample size and close correlation between demand proxies make it likely to observe spurious results, so the health expenditure and top $10 \%$ GNI variables are dropped because of their respective correlations with GNI of 0.91 and 0.95 . The demand proxies have little joint explanatory power, demonstrated by the low adjusted $\mathrm{R}^{2}$ values in columns 1 and 2. The magnitudes of the coefficients are difficult to interpret, but per-capita GNI has consistently insignificant effects. Similar to the finding by Scherer and Watal, there is some evidence that having more HIV/AIDS cases lowers the AIDS drug price. Inequality is somewhat associated with higher prices, though the result is driven by outliers in GINI values (Jamaica, Trinidad and Tobago), as is shown by the lack of a significant result in the robust regressions.

Without an accompanying positive effect of GNI on prices, it would be tenuous to interpret this evidence as suggesting unconstrained monopolist pricing. Replacing GNI with top $10 \%$ GNI or health expenditures produces the same insignificant results, suggesting that prices are not kept high to capture rents from wealthy elites or higher government budgets.

By contrast, both the total and per-capita illicit drug variables are consistently statistically significant predictors of a country's AIDS drug price and typically add substantial explanatory power to the regressions. When many regressions are run on a small sample, there is a large potential for spurious results. Thus, it is important to focus on the only stable and robust result: that a country's involvement in the illicit drug trade increases the price at which pharmaceutical companies are willing to sell AIDS drugs. The theory in Section III and, in particular, Figure 2 implies that prices in poorer countries will be determined either by domestic demand or by the black market constraint. When forced to choose between these two theories, the bulk of the empirical evidence indicates that smuggling concerns are the dominant determinant of price. 
Hornbeck: Price Discrimination and Smuggling of AIDS Drugs

Table 4. OLS regression of 2002 AIDS drug price on:

\begin{tabular}{|c|c|c|c|c|c|c|}
\hline & (1) & (2) & (3) & (4) & $(5)$ & (6) \\
\hline Drug Money & & & $\begin{array}{c}0.494 \\
(0.104)^{* *}\end{array}$ & $\begin{array}{c}0.432 \\
(0.129)^{* *}\end{array}$ & & \\
\hline $\begin{array}{r}\text { Drug Money } \\
\text { per-capita }\end{array}$ & & & & & $\begin{array}{c}20.5 \\
(11.4)+\end{array}$ & $\begin{array}{c}29.1 \\
(8.4)^{* *}\end{array}$ \\
\hline GNI per-capita & $\begin{array}{l}-0.040 \\
(0.167)\end{array}$ & $\begin{array}{c}0.259 \\
(0.239)\end{array}$ & $\begin{array}{l}-0.096 \\
(0.104)\end{array}$ & $\begin{array}{l}-0.027 \\
(0.184)\end{array}$ & $\begin{array}{l}-0.041 \\
(0.155)\end{array}$ & $\begin{array}{c}0.259 \\
(0.161)\end{array}$ \\
\hline $\begin{array}{l}\text { GINI } \\
\quad \text { coefficient }\end{array}$ & & $\begin{array}{c}177.2 \\
(80.8)^{+}\end{array}$ & & $\begin{array}{c}87.1 \\
(61.4)\end{array}$ & & $\begin{array}{c}231.1 \\
(56.6)^{* *}\end{array}$ \\
\hline $\begin{array}{l}\text { HIV/AIDS } \\
\text { cases }\end{array}$ & $\begin{array}{l}-1.56 \\
(2.41)\end{array}$ & $\begin{array}{c}-5.16 \\
(2.73)+\end{array}$ & $\begin{array}{l}-2.21 \\
(1.49)\end{array}$ & $\begin{array}{c}-3.70 \\
(1.92)+\end{array}$ & $\begin{array}{l}-0.44 \\
(2.32)\end{array}$ & $\begin{array}{c}-4.42 \\
(1.85)^{*}\end{array}$ \\
\hline EFV dummy & $\begin{array}{l}-692 \\
(902)\end{array}$ & $\begin{array}{l}-976 \\
(922)\end{array}$ & $\begin{array}{l}-355 \\
(559)\end{array}$ & $\begin{array}{l}-564 \\
(642)\end{array}$ & $\begin{array}{l}-679 \\
(834)\end{array}$ & $\begin{array}{l}-963 \\
(620)\end{array}$ \\
\hline Constant & $\begin{array}{c}3,178 \\
(1,173)^{*}\end{array}$ & $\begin{array}{l}-6,330 \\
(4,519)\end{array}$ & $\begin{array}{c}2,616 \\
(731)^{* *}\end{array}$ & $\begin{array}{l}-1,762 \\
(3,374)\end{array}$ & $\begin{array}{c}2,316 \\
(1,185)+\end{array}$ & $\begin{array}{l}-10,387 \\
(3,259)^{*}\end{array}$ \\
\hline Adjusted $\mathrm{R}^{2}$ & -0.15 & 0.16 & 0.56 & 0.61 & 0.02 & 0.62 \\
\hline Observations & 17 & 14 & 17 & 14 & 17 & 14 \\
\hline
\end{tabular}

Table 5. Robust regression with Huber weights of 2002 AIDS drug price on:

\begin{tabular}{|c|c|c|c|c|c|c|}
\hline & (1) & (2) & (3) & (4) & (5) & (6) \\
\hline Drug Money & & & $\begin{array}{c}0.685 \\
(0.089)^{* *}\end{array}$ & $\begin{array}{c}0.637 \\
(0.076)^{* *}\end{array}$ & & \\
\hline $\begin{array}{r}\text { Drug Money } \\
\text { per-capita }\end{array}$ & & & & & $\begin{array}{c}48.8 \\
(12.1)^{* *}\end{array}$ & $\begin{array}{c}43.5 \\
(14.7)^{*}\end{array}$ \\
\hline GNI per-capita & $\begin{array}{l}-0.000 \\
(0.106)\end{array}$ & $\begin{array}{c}0.226 \\
(0.280)\end{array}$ & $\begin{array}{c}-0.002 \\
(0.064)\end{array}$ & $\begin{array}{c}0.034 \\
(0.109)\end{array}$ & $\begin{array}{c}-0.131 \\
(0.121)\end{array}$ & $\begin{array}{c}0.046 \\
(0.250)\end{array}$ \\
\hline $\begin{array}{l}\text { GINI } \\
\text { coefficient }\end{array}$ & & $\begin{array}{l}169.7 \\
(94.7)\end{array}$ & & $\begin{array}{c}62.5 \\
(36.4)\end{array}$ & & $\begin{array}{l}136.5 \\
(97.6)\end{array}$ \\
\hline $\begin{array}{l}\text { HIV/AIDS } \\
\text { cases }\end{array}$ & $\begin{array}{l}-1.18 \\
(1.53)\end{array}$ & $\begin{array}{l}-4.98 \\
(3.20)\end{array}$ & $\begin{array}{c}-1.77 \\
(0.91)^{+}\end{array}$ & $\begin{array}{c}-2.84 \\
(1.14)^{*}\end{array}$ & $\begin{array}{l}-0.44 \\
(1.77)\end{array}$ & $\begin{array}{l}-2.55 \\
(2.50)\end{array}$ \\
\hline EFV dummy & $\begin{array}{c}835 \\
(570)\end{array}$ & $\begin{array}{c}-811 \\
(1,080)\end{array}$ & $\begin{array}{c}606 \\
(370)\end{array}$ & $\begin{array}{c}465 \\
(381)\end{array}$ & $\begin{array}{c}-92 \\
(653)\end{array}$ & $\begin{array}{l}-578 \\
(758)\end{array}$ \\
\hline Constant & $\begin{array}{c}1,392 \\
(741)+\end{array}$ & $\begin{array}{l}-5,986 \\
(5,295)\end{array}$ & $\begin{array}{c}1,332 \\
(472)^{*}\end{array}$ & $\begin{array}{l}-1,759 \\
(2,002)\end{array}$ & $\begin{array}{c}1,671 \\
(920)+\end{array}$ & $\begin{array}{l}-5,506 \\
(5,343)\end{array}$ \\
\hline Adjusted $\mathrm{R}^{2}$ & 0.00 & 0.01 & 0.80 & 0.89 & 0.48 & 0.57 \\
\hline Observations & 17 & 14 & 16 & 14 & 16 & 13 \\
\hline
\end{tabular}


That AIDS drug firms are setting prices based on the potential for smuggling does not imply an absolute lower bound on prices. The model in Section III is highly stylized, as it does consider threats to remove patent protection or an imperfect ability to predict smuggling thresholds. Since 2002, there have been price cuts on paper for different drugs, but prices are still high and distributed quantities are constrained (Outterson, 2005; UNAIDS, 2005; PAHO 2005). ${ }^{16}$ The purpose of this price analysis is not to identify a lower bound on prices, but to reveal firms forgoing increased profits in poorer countries to prevent smuggling to richer markets. This demonstrates that widespread AIDS drug distribution in the developing world, without further barriers to smuggling, would undermine profits from developed markets.

There is also strong anecdotal evidence that smuggling is a major concern for pharmaceutical companies. In all negotiated price agreements, countries must nominally commit to prevent smuggling to other countries, particularly from poorer countries to richer countries. ${ }^{17}$ Merck, the patent-holder for the AIDS drug $\mathrm{EFV}$, has developed delivery methods and distinctive packaging to discourage smuggling. ${ }^{18}$ The European Union has launched a plan to use logos on discounted drugs to prevent re-importation. ${ }^{19}$ There is also evidence suggesting that firms will limit the quantity of drugs they supply to Canada if sales to the United States are not stopped. ${ }^{20}$

When smuggling is less of a concern, international initiatives have been very successful at obtaining medicines at much lower prices. This is particularly clear in the case of vaccines, where black market demand in the developed world is minimal and multilateral organizations often prevent diversion by handling the distribution and administration themselves (JFK, 1997). Even for AIDS drugs, GlaxoSmithKline has been more willing to lower prices when charitable organizations were able to ensure their intended use in developing countries. ${ }^{21}$

${ }^{16}$ Care is necessary in interpreting coverage statistics as fewer people are deemed to require treatment in "resource-limited settings," where it is recommended that treatment start later. The lower percentage of infected people requiring treatment, compared to the United States, leads to overly optimistic coverage statistics. There is also little availability of "second-line" drugs such as EFV, one of the drugs analyzed above. Government commitments and goals to provide drugs to those who require them also create incentives to understate the remaining need.

17 Heywood M., "World AIDS Day Teleconference Transcript." Member of Treatment Action Campaign, November 28, 2000; Inter Press Service, "Victory in Fight for Low-Cost AIDS Drugs." January 30, 2003.

18 Wall Street Journal, "Merck to Cut Stocrin Price In the Poorest Countries." October 23, 2002.

19 Associated Press, "Low-Cost Drugs for Poor Countries Urged." May 26, 2003.

20 Associated Press, "Canada to Ban Bulk Exports of Rx Drugs." June 29, 2005; USA Today, "Glaxo wants to keep cheaper drugs out of USA." January 21, 2003.

21 Faber, G., WTO/WHO Presentation (GlaxoSmithKline), WHO-WTO Hosbjor Conference, 2001; Financial Times, "Glaxo Cuts Price of HIV Medicine." February 22, 2001. 
Some propose that companies are hesitant to lower prices in poorer countries for fear of causing a backlash in richer markets (Kremer, 2002; Hammer, 2002). One proposed cause of this backlash is the revelation of low marginal costs. This explanation, however, presupposes that there are currently information asymmetries, but marginal costs are already known to be much lower than prices in developed countries. A second proposed source of backlash stems from the violation of perceived fairness. In the United States there is a current frustration with rising drug costs, but in an absolute sense or in comparison to Canada, rather than relative to poorer countries. Some have purposefully not pushed for comparable price cuts in the United States for fear of jeopardizing price cuts in Africa. ${ }^{22}$ There is no clear reason why these perceptions would allow prices to differ by an order of magnitude but no further.

Wherever cheap drugs are available, they are susceptible to entering the black market to be sold elsewhere. In Sweden, a woman attempted to exploit the public health care system to buy cheap drugs and export them to Eastern Europe. $^{23}$ In Chile, poorer citizens receiving free drugs from the government have sold them, even as more drugs are smuggled into Chile, where an estimated $10-15 \%$ of anti-retrovirals are sold on the black market. ${ }^{24}$

Smuggling rings have been discovered that aimed to resell in Europe those drugs destined for Africa. ${ }^{25}$ Contrary to the indications of early press reports, these are not examples of substantial arbitrage (see Outterson), but they demonstrate the desire and infrastructure for exploiting arbitrage possibilities. Recall from Section III that the presence of the Black Market would not result in substantial smuggling; rather, those seeking to exploit arbitrage potential would be kept on the brink of opportunity. These small attempts merely reflect the fringe of the larger forces being kept at bay by restrained distribution. Once smuggling incentives pass the critical threshold, smuggling would become rampant until "street" prices responded and the previous price differential was reestablished. Smuggling would emerge especially rapidly if there were important fixed costs to be overcome before entry was profitable.

Similarly, when Outterson argues that only small quantities are available on the local level for diversion, this is only a reflection of the current restrained distribution. The ultimate policy goal is to obtain widespread distribution of AIDS drugs throughout the developing world, which is when the threat of

${ }^{22}$ Wall Street Journal, "US drug buyers unlikely to seek deep discounts on AIDS medicines." March 23, 2001.

23 Associated Press, "Woman in Sweden accused of buying HIV drugs with fake prescriptions." March 12, 2003.

${ }^{24}$ BBC News, "Chileans "trading AIDS drugs for food." July 11, 2002.

${ }^{25}$ BBC News, "Industry tackles AIDS drug scandal." October 3, 2002; Washington Post, "HIV Drugs for Africa Diverted to Europe." October 2, 2002; Washington Times, "African AIDS Pills Hit Black Market.” December 30, 2002. 
smuggling would fully materialize. The current market only offers clues of what would occur when the developing world is saturated with AIDS drugs: clues such as the apparent eagerness of arbitragers and firms' willingness to sacrifice profits and their public image to prevent smuggling.

Citizens' desire to participate in arbitrage and black market dealings is not limited to poorer countries. An estimate of the value of prescription drugs smuggled from Canada to the United States is $\$ 650$ million and growing (Graham, 2003). In California, publicly provided AIDS drugs were diverted away from AIDS patients to assist body builders and give an energy boost. ${ }^{26}$ The AIDS drug ddC faced strong black market demand when regulatory approval was stalled in the United States. ${ }^{27}$ It may be true that the black market faces commitment problems in providing actual drugs rather than counterfeits (Outterson), but price discounts can compensate for this risk. In addition, this commitment problem can be overcome through the standard reputation mechanisms and by the distinctive packaging and coloring of drugs that are needed to prevent them from being introduced at a higher stage of the supply chain.

It is tempting to compare the incentives for smuggling illicit drugs and AIDS drugs. The ODCCP report and PAHO data would imply an AIDS drug price differential around half of that for cocaine and marijuana, while Outterson estimates approximately equal price differentials. Outterson concludes that the lack of current AIDS drug smuggling in the face of such potential indicates that it is never likely to occur. This comparison can be misleading, however, given the differences in destination consumer markets. Consumers in richer markets may often pay a lower out-of-pocket expense for AIDS drugs purchased through government programs or an insurance plan that is partially subsidized by other insurance holders or an employer.

Of course, if all consumers in richer markets received AIDS drugs for free, there would be no market for smugglers; this is not, nor ever likely to be, the case, however. Even when the price appears to be low, consumers often still pay a higher price for the drugs through insurance premiums or fees for additional third party prescription plans. This is true for employer-provided insurance to the extent that there are lower-benefit higher-wage options available in the labor market. Richer countries often supply AIDS drugs through government programs, but there are typically income maximums and benefit limits. Also, governments may reduce their provision of drugs when consumers can acquire them elsewhere at a lower cost, e.g., the budget choices faced by border states when faced with arbitrage between the United States and Canada.

\footnotetext{
${ }^{26}$ Los Angeles Times, "Black Market in AIDS Drug Flourishes: Control of hormone is laxer in California than elsewhere. Medi-Cal says it has stiffened rules." February 16, 2003.

27 USA Today, “Trade in Illicit AIDS Drugs Brisk.” June 17, 1991.
} 
Hornbeck: Price Discrimination and Smuggling of AIDS Drugs

\section{Implications of a relevant smuggling threat for AIDS drug policy}

Encouraging both the discovery of new AIDS drugs and lower prices in developing countries for existing drugs is only part of the fight against AIDS, but it is a critical part. Policy designed to lower prices and spread access to drugs must be combined with efforts to prevent smuggling. It is not enough to ban "parallel trade," as there will be a strong incentive to circumvent such laws. Without strong enforcement efforts, drugs will be diverted to other markets, creating shortages and raising prices. Even where drugs remain, supply will likely fluctuate, leading to sporadic use among patients and the development of resistance to the drug therapy, even if the medicine supply remains authentic and safe. The spread of smuggled drugs will support the rise of organized crime and violence, just as has been the case with the current illicit drug trade.

A simple calculation reveals the potential for smuggled drugs to undercut total research incentives in the global pharmaceutical industry. In 2001, of those living with AIDS in the developing world, six million were considered to require anti-retroviral AIDS drugs, while 230,000 received treatment. ${ }^{28}$ In the West, half a million people received anti-retroviral treatment. If all of those who required treatment in the developing world received the drugs at cost and 5\% were smuggled into the West for purchase by previous consumers, it would supplant $60 \%$ of that market, severely undermining profits and research incentives.

This smuggling threat means that intellectual property policy for the developing world cannot be designed in a vacuum. Proposals to eliminate patent protection in only the developing world (Lanjouw, 2001) are problematic because smuggling from those countries would weaken the effects of patent protection in the developed world. Negotiation threats to allow generic competition in the absence of price cuts amount to the same policy. Smuggling would undercut any policy to isolate a single poorer market and subsidize drugs, buy-out the patents (Kremer, 1998), or otherwise provide universal coverage.

Establishing barriers to smuggling in the international market is an important goal not only because it improves the efficiency of the patent system, but because it makes these other policy options more effective and more politically expedient. Once markets are isolated, patent laws could be selectively eliminated or bought-out. Countries have an incentive to import black market drugs, but also have a strong unilateral incentive to prevent their drugs from being exported. By preventing smuggling, a country would secure lower prices and avoid the health effects of supply disruptions. Thus, there would be no free rider problem in preventing diversions.

${ }^{28}$ UNAIDS 2002b; BBC 2002. 
It will be difficult to prevent smuggling under widespread AIDS drug distribution, but control over the distribution of legal drugs has an inherent advantage over illicit drugs - namely, governments would start in control of the drugs and would share a common goal with the producers. Careful drug administration and packaging have been successful in a variety of situations (Hammer, 2002). Also, if relatively minor technological improvements could allow pills to be administered less frequently and under supervision at a clinic, the potential for resale would be greatly reduced. Finally, many of the resources spent to increase market segmentation would overlap with improvements in countries' health infrastructure. ${ }^{29}$

While it is always difficult to separate countries' markets, some policies actively work against this goal. Some countries, such as Canada, have used price controls that tie their price to those in a bundle of other countries, often poorer countries. Thus, if a firm wished to charge a higher price in Canada, it would be encouraged to charge higher prices in the bundle countries. Additionally, donations of money to buy AIDS drugs artificially bring donors into poorer countries' demand, encouraging higher prices as companies respond to donors' demand. ${ }^{30}$ Finally, many countries in Latin America and the Caribbean have recently adopted a joint uniform price policy in an effort to increase their bargaining power, but this policy prevents likely beneficial price discrimination.

If governments avoided these policies and offered their cooperation, firms would have incentives to prevent smuggling and distribute drugs. Private gains to profits and public relations would be less than is socially optimal, but it would be a start. Preventing smuggling often would not require initial investment on the part of the poor country, balancing of competing domestic interests, or international coordination. For the poorest countries, further international price discrimination would come close to benefiting them without any detrimental effects, as there would be very little effect on prices in the developed world.

One main reason that this coordination of anti-smuggling efforts has failed to materialize is the strong antagonism between countries and pharmaceutical companies. Even if a firm were willing to make anti-smuggling investments, it would often require government coordination and cooperation. To the extent that firms may invest too little in market segmentation, governments may need to contribute as well. Where traditional donations may just encourage high prices and subsidize purchases by a country's elite, foreign aid to increase market segmentation could truly extend drug access to developing countries' poorest citizens.

\footnotetext{
${ }^{29}$ See Granville for further discussion of methods to increase market segmentation.

${ }^{30}$ See Scherer and Watal for a further discussion of the price control effect and a proposal for structuring drug donations that would avoid these concerns.
} 
Hornbeck: Price Discrimination and Smuggling of AIDS Drugs

\section{Conclusion}

The widespread distribution of anti-retroviral AIDS drugs would be a major breakthrough in combating the AIDS epidemic. However, prices for current and future AIDS drugs must remain high in the developed world to encourage the research and development of new medicines. Obtaining both of these objectives widespread drug distribution and the encouragement of research and development - requires that markets in the developed world remain insulated from drugs available at low prices in the developing world.

Given the current potential for diverting, smuggling, and selling AIDS drugs, universal access to AIDS drugs priced near marginal cost in poorer countries would be impossible without flooding the market in developed countries. This much is revealed by firms' reluctance to lower prices in the developing world, a step which otherwise would bring greater profits and public relations benefits.

To improve access to AIDS drugs and maintain research incentives, policy focus should shift from reducing firms' market power to improving market segmentation and the viability of price discrimination. Separating international markets through additional barriers to smuggling would increase social welfare under both a global patent system and a two-tiered system maintaining patent protection only in richer countries. The initial steps toward further market segmentation can be driven by firms' profit incentives and public relations goals, but the bulk of the benefit is to be reaped by poorer countries. Thus, governments must coordinate and support this effort through international law, criminal enforcement, and investments in health infrastructure. Antagonism, mistrust, and government policies that undercut such an effort must be avoided. It is imperative for society both to extend access to these life-saving medicines and to commit itself to encouraging further research. 
Topics in Economic Analysis \& Policy, Vol. 5 [2005], Iss. 1, Art. 16

\section{References}

Anderson, S. and Ginsburgh, V.A. 1999. "International Pricing with Costly Consumer Arbitrage." Review of International Economics, Vol. 7, No. 1, pp. 126-139.

Ganslandt, M. and Maskus, K.E. 2004. "Parallel imports and the pricing of pharmaceutical products: evidence from the European Union." Journal of Health Economics, Vol. 23, No. 5, pp. 1035-1057.

Graham, J.R. 2003. "Prescription Drug Prices in Canada and the United States Part 4: Canadian Prescriptions for American Patients Are Not the Solution." Public Policy Sources, Vol. 70, September.

Granville, B. (editor). 2002. The Economics of Essential Medicines. Royal Institute of International Affairs, 10 St. James's Square, London SW1Y 4LE.

Hammer, P.J. 2002. "Differential Pricing of Essential AIDS Drugs: Markets, Politics, and Public Health." Journal of International Economic Law, Vol. 5, No. 4, pp. 883-912.

Hausman, J.A. and Mackie-Mason, J.K. 1988. "Price Discrimination and Patent Policy." Rand Journal of Economics, Vol. 17, No. 2, pp. 253-265.

John F. Kennedy School of Government (JFK), Harvard University. 1997. "Vaccines for the Developing World: The Challenge to Justify Tiered Pricing." Case studies 1450 and 1450.1.

Kremer, M. 1998. "Patent Buyouts: A Mechanism for Encouraging Innovation." Quarterly Journal of Economics, Vol. 113, No. 4, pp. 1137-1167.

- - 2002. "Pharmaceuticals and the Developing World." Journal of Economic Perspectives, Vol. 16, No. 4, pp. 67-90.

Lanjouw, J. 2001. "A Patent Policy Proposal for Global Diseases.” The Brookings Institution, Policy Brief No. 84, June.

Layson, S.K. 1994. "Market Opening under Third-Degree Price Discrimination." The Journal of Industrial Economics, Vol. 42, No. 3, pp. 335-340. 
Hornbeck: Price Discrimination and Smuggling of AIDS Drugs

Malueg, D.A. and Schwartz, M. 1994. "Parallel imports, demand dispersion, and international price discrimination." Journal of International Economics, Vol. 37, No. 3-4, pp. 167-195.

Outterson, K. 2005. "Pharmaceutical Arbitrage: Balancing Access and Innovation in International Prescription Drug Markets." Yale Journal of Health Policy, Law, and Ethics, Winter.

Pan American Health Organization (PAHO). 2002. "Average prices of a one year treatment with anti-retrovirals in countries of Latin America and the Caribbean."

- - 2005. "ART (Antiretroviral therapy) coverage in the Region of the Americas." June.

Phlips, L. 1983. The Economics of Price Discrimination. Cambridge University Press, The Edinburgh Building, Shaftesbury Road, Cambridge, CB2 2RU.

Scherer, F.M. and Watal, J. 2002. "Post-trips options for access to patented medicines in developing nations." Journal of International Economic Law, Vol. 5, No. 4, pp. 913-939.

Schmalensee, R. 1981. "Output and Welfare Implications of Monopolistic ThirdDegree Price Discrimination.” American Economic Review, Vol. 71, p. 242-7.

Tirole, J. 1988. The Theory of Industrial Organization. MIT Press, 55 Hayward Street, Cambridge, MA 02142-1493.

UNAIDS. 2002a. "Accelerating Access Initiative: Widening access to care and support for people living with HIV/AIDS." June.

——. 2002b. "Report on the global HIV/AIDS epidemic." July.

——. 2005. "Progress on Global Access to HIV Antiretroviral Therapy: An update on '3 by 5." June.

United Nations Office of Drug Control and Crime Prevention (ODCCP). 2001. "Global Illicit Drug Trends 2001." ODCCP Studies on Drugs and Crime: Statistics. June 26, 2001.

Varian, H.R. 1985. "Price Discrimination and Social Welfare." American Economic Review, Vol. 75, pp. 870-875. 